J. Product. \& Dev., 26(3):531- 559(2021)

\title{
LAYING PERFORMANCE, HEALTH STATUS and SOME PHYSIOLOGICAL TRAITS Of MANDURAH LAYING CHICKENS AFFECTED BY THE ADDITION OF DIFFERENT LEVELS of ANISE AND CARAWAY SEED POWDER
}

\author{
Ayman, A. Soliman ${ }^{1}$; Abdel-Azeem, F. Abdel-Azeem ${ }^{2 *}$ and El-Sayed, M. EL-Sisi ${ }^{1}$ \\ ${ }^{1}$ Animal Production Research Institute, ARC, Ministry of Agricultural, Dokki, \\ Giza, Egypt. \\ ${ }^{2}$ Department of Animal Production, Faculty of Agriculture, Al-Azhar University, \\ Nasr City, Cairo, Egypt.. \\ * Corresponding author: abdelazeem.fahmy@yahoo.com
}

\section{ABSTRACT:}

This study was conducted to evaluate the effects of varying levels of Anise and Caraway seeds powder on laying performance, some blood constituents, egg quality traits, yolk cholesterol content, immunity response and total count aerobic bacteria of Mandurah laying chicken. For this purpose, a total number of 140 Mandurah laying chickens at 26 weeks of age were used in this experiment having a completely randomized design, with 7 equal treatment groups, which replicated 4 times with 5 hens per replicate. Each bird was housed in individual wire cage measuring $\left(50 \times 50 \times 45 \mathrm{Cm}^{2}\right)$, where each bird in each cage allowing 510 $\mathrm{Cm}^{2}$ space/hen). A basal control diet was formulated and supplemented with 0.1, 0.2 and 0.3 \% Anise and 0.1, 0.2 and 0.3\% Caraway seeds in powder form. Birds were fed on isocaloric $(2751 \mathrm{Kcal} \mathrm{ME} / \mathrm{Kg})$ and isonitrogenous $(16.14 \% \mathrm{CP})$ diets. Results showed that laying performance significantly $(P<0.05)$ improved when inclusion Anise and Caraway seeds powder compared with the control group. However, it was clearly observed that plasma lipids were significantly reduced $(P<0.05)$ by supplementing diets with different levels of anise and caraway seeds. In the same trend, the addition of Anise and Caraway seeds powder led to a clear and significant decrease in egg yolk and blood cholesterol compared with the control group $(P<0.05)$. However, Anise and Caraway seed powder incorporation caused positive effects on the parameters related to immune response and overall total antioxidant capacity (TAC) compared with the control group. While, total count aerobic bacteria significantly ( $P$ $<0.05)$ decreased for birds fed diets inclusion Anise and Caraway seeds powder as compared with the control group. 
Conclusively, Anise and Caraway seeds powder can be included in the diet of laying hens as a safe and effective feed additive to improve laying performance and reduce total blood lipids and thus reduce cholesterol content in egg yolk.

Key words: Laying performance, health status, and physiological traits.

\section{INTRODUCTION:}

The industrialization of poultry husbandry and the improvement of feed nutritional efficiency has speeded up the introduction of the feed additives that have become widely used in animal feed for many decades. Therefore, phytogenic feed additives have been extensively studied to improve poultry performance, where phytogenic products are derived from a group of popular medicine herbal plants (Bozkurt et al., 2014). However, phytochemicals in herbal plants have stimulating effects on poultry digestive system and exhibit antioxidant, antimicrobial, antifungal, and anti-inflammatory, as well as anti-parasitic and antiprotozoal properties (Hajati et al., 2014; Achilonu et al., 2018).

Nowadays, comprehensive investigations of phytogenic plants have indicated their growth promoting, antimicrobial, antioxidant and anti-inflammatory functions (Gheisar and Kim, 2017). The herbal plants have recently gained increasing interest, due to its bioactive content of phytochemicals which comprise phenolic, polyphenols, alkaloids, lectins, terpenoids, polypeptides and essential oils (Gheisar and Kim, 2018). Among these species, Caraway (Carum carvi) is one of the most appreciate spices for its seed richness, plethora of bio-logically active compounds and medicinal agent (Laribi et al. 2010). However, Seger et al. (2019) indicated that the inclusion of Caraway seed powder at levels 4, 6 and $8 \mathrm{~g} /$ $\mathrm{kg}$ of Japanese quail diet did not affect the growth and development of the gonads as well as the proportion of lipids in the blood. However, Anise (Pimpinella anisum L.) is an annual aromatic herb belonging to the Apiaceae family and has been widely used to maintain or improve animal and human health (Al-Shammari et al., 2017). Thus, Christaki et al. (2011) found that neither the supplementation of Anise nor that of $\alpha$-tocopheryl had any effect on the performance of the birds or the quality of their eggs, except for a significant change of the color of the egg yolk. They added that cholesterol concentration in the serum tended to decrease with the addition of Anise to the diet.

Therefore, the present study aimed to evaluate the effect of inclusion different levels of Anise and Caraway seed powered on laying performance, 
some blood constituents, egg quality traits, yolk cholesterol content, immunity response and total count aerobic bacteria of Mandurah laying chickens.

\section{MATERIALS AND METHOD}

Site, duration, and the aim of the present study.

The present study was carried out at the Anshas Poultry Breeding Research Station belonging to the Animal Production Research Institute (APRI), Agriculture research center, Cairo, A.R.E., between the periods of September 2015 to February 2016. Therefore, the present study aimed to evaluate the effect of inclusion different levels of Anise and Caraway seed powered on laying performance, some blood constituents, egg quality traits, yolk cholesterol content, immunity response and total count aerobic bacteria of Mandurah laying chickens.

\section{Husbandry, experimental design and feeding practice.}

Before the start of the experiment the experimental unit which will be used in this study was cleaned and fumigated with a mixture of potassium permanganate $(17.5 \mathrm{~g})$ and formalin solution $(35 \mathrm{~mL})$ to eliminate any pathogen can affect bird's health afterwards. After fumigation the unit, batteries and tools were prepared for the experiment. A total number of 140 Mandurah laying chicken with uniform body weight were randomly assigned to a completely randomized design, with 7 equal treatment groups replicated 4 times with 5 hens per replicate. Each bird was housed in individual wire cage measuring $(50 \times 50 \times$ $45 \mathrm{Cm}^{2}$ ), where each bird in each cage allowing $510 \mathrm{Cm}^{2}$ space/hen). Laying hens in the control group were given a corn-soybean-basal diet in pellet form without any supplementation. While, the other treatment groups were given the same basal diet supplemented with $0.1,0.2$ and $0.3 \%$ Anise seed powder (ASP) and $0.1,0.2$ and $0.3 \%$ Caraway seed powder (CSP). All diets were isocaloric $(2751 \mathrm{Kcal} \mathrm{ME} / \mathrm{Kg})$ and isonitrogenous $(16.14 \% \mathrm{CP})$. Diets were formulated to provide the nutrient requirements according to NRC (1994).

Anise and Caraway seeds powder was first mixed with premix which was later mixed with other ingredients and then pelleted. Samples of rations and both seeds powder were taken in to perform routine and bioactive chemical analysis according to AOAC (1994) as shown in Tables (1 and 2). The laying hens were kept in optimal and standard bioclimatic and welfare conditions with ad libitum feeding and watering. The temperature degree was between 25 to $30{ }^{\circ} \mathrm{C}$ with relative humidity of $60-65 \%$, which were recorded by using a digital thermohygrometer at 9:00 a.m. to 7:00 p.m. Chickens were provided 16 hour of light: 
Table (1): Ingredients and nutrients composition of the basal diet (air-dry basis).

\begin{tabular}{|c|c|c|c|c|c|c|c|}
\hline \multirow[b]{2}{*}{ Ingredients } & \multirow{2}{*}{$\begin{array}{c}\text { Control } \\
\text { diet }\end{array}$} & \multicolumn{3}{|c|}{ Anise level \% } & \multicolumn{3}{|c|}{ Caraway level \% } \\
\hline & & 0.1 & 0.2 & 0.3 & 0.1 & 0.2 & 0.3 \\
\hline Yellow corn $(8.5 \%)$ & 65.5 & 65.42 & 65.35 & 65.27 & 65.43 & 65.37 & 65.31 \\
\hline $\begin{array}{l}\text { Soybean meal (44 } \\
\% \mathrm{CP}\end{array}$ & 25.0 & 24.97 & 24.9 & 24.92 & 24.96 & 24.93 & 24.89 \\
\hline Limestone $\left(\mathrm{CaCo}_{3}\right)$ & 7.10 & 7.10 & 7.10 & 7.10 & 7.10 & 7.10 & 7.10 \\
\hline $\begin{array}{l}\text { Di-calcium phosphate( } \\
\left.\text { CaHPO }_{4}\right)\end{array}$ & 1.50 & 1.50 & 1.50 & 1.50 & 1.50 & 1.50 & 1.50 \\
\hline DL-Methionine 99\% & 0.10 & 0.10 & 0.10 & 0.1 & 0.10 & 0.10 & 0.10 \\
\hline $\begin{array}{l}\text { Sodium chloride } \\
(\mathrm{NaCl})\end{array}$ & 0.40 & 0.40 & 0.40 & 0.40 & 0.40 & 0.40 & 0.40 \\
\hline Vit \& Min. Premix* & 0.40 & 0.40 & 0.40 & 0.40 & 0.40 & 0.40 & 0.40 \\
\hline Anise seed powder & 0.00 & 0.10 & 0.20 & 0.30 & 0.00 & 0.00 & 0.00 \\
\hline Caraway seed powder & 0.0 & 0.0 & 0.00 & 0.00 & 0.10 & 0.20 & 0.30 \\
\hline Total $(\mathrm{Kg})$ & 100 & 100 & 100 & 100 & 100 & 100 & 100 \\
\hline \multicolumn{8}{|l|}{ a-Calculated analysis $* *$} \\
\hline Crude protein $(\%)$ & 16.14 & 16.22 & 16.19 & 16.15 & 16.12 & 16.20 & 16.19 \\
\hline $\begin{array}{l}\text { Metabolizable energy } \\
\text { (Kcal/Kg.) }\end{array}$ & 2752 & 2750 & 2751 & 2753 & 2750 & 2753 & 2751 \\
\hline Calcium (\%). & 3.04 & 3.08 & 3.06 & 3.03 & 3.05 & 3.04 & 3.07 \\
\hline $\begin{array}{l}\text { Available phosphorus } \\
(\%) .\end{array}$ & 0.41 & 0.45 & 0.43 & 0.44 & 0.43 & 0.45 & 0.42 \\
\hline Lysine $(\%)$. & 0.89 & 0.88 & 0.90 & 0.87 & 0.88 & 0.89 & 0.86 \\
\hline Methionine (\%) & 0.39 & 0.40 & 0.38 & 0.37 & 0.41 & 0.39 & 0.40 \\
\hline $\begin{array}{l}\text { Methionine + Cystine } \\
(\% .)\end{array}$ & 0.56 & 0.57 & 0.60 & 0.59 & 0.56 & 0.55 & 0.57 \\
\hline \multicolumn{8}{|l|}{ b-Chemical analysis } \\
\hline Crude protein $(\%)$. & 16.24 & 16.33 & 16.22 & 16.25 & 16.17 & 16.21 & 16.24 \\
\hline Crude fiber (\%). & 3.22 & 3.23 & 3.33 & 3.19 & 3.31 & 3.27 & 3.25 \\
\hline $\operatorname{Ash}(\%)$ & 2.24 & 2.26 & 2.28 & 2.22 & 2.28 & 2.30 & 2.34 \\
\hline
\end{tabular}

*Vitamin and mineral premix supplied per kg of diet: Vitamin A 12,000 IU, vitamin $\mathrm{D}_{3} 3,000 \mathrm{IU}$, vitamin $\mathrm{E} 40 \mathrm{mg}$, vitamin $\mathrm{K}_{3} 3 \mathrm{mg}$, vitamin $\mathrm{B}_{1} 2 \mathrm{mg}$, vitamin $\mathrm{B}_{2} 6 \mathrm{mg}$, vitamin $\mathrm{B}_{6} 5 \mathrm{mg}$, vitamin $\mathrm{B}_{12} 0.02 \mathrm{mg}$, niacin $45 \mathrm{mg}$, biotin $0.075 \mathrm{mg}$, folic acid $2 \mathrm{mg}$, pantothenic acid $12 \mathrm{mg}$, manganese $100 \mathrm{mg}$, zinc $600 \mathrm{mg}$, iron $30 \mathrm{mg}$, copper $10 \mathrm{mg}$, iodine $1 \mathrm{mg}$, selenium $0.2 \mathrm{mg}$, cobalt $0.1 \mathrm{mg}$.

**Calculated analysis was performed according to $(\mathrm{NRC}, \mathbf{1 9 9 4})$

Eight hours of dark cycle's program using automatic timers to schedule the lighting regimens with light intenesity15 to $20 \mathrm{~lx}$ throughout the entire experimental period. The cages were equipped with a nipple drinker and trough feeders, where all feeding conditions among treatments were the same 
Table 2: Proximate analysis and bio-active components of Anise and Caraway seeds powder.

\begin{tabular}{|c|c|c|}
\hline \multirow[t]{2}{*}{ Items } & \multicolumn{2}{|c|}{ Medicinal plants } \\
\hline & Anise seed powder & Caraway seed powder \\
\hline \multicolumn{3}{|l|}{ Chemical composition (\%) } \\
\hline Moisture & 10.40 & 9.78 \\
\hline Dray matter & 89.60 & 90.22 \\
\hline Crude protein & 17.40 & 20.03 \\
\hline Ash & 10.14 & 11.61 \\
\hline Crude fiber & 14.7 & 20.16 \\
\hline Ether extract & 27.09 & 20.96 \\
\hline \multicolumn{3}{|l|}{ Bio-active components (\%) } \\
\hline Limonene & 1.4199 & 2.35 \\
\hline a-phellandrene & 1.4546 & 2.406 \\
\hline Fenchene & 1.4807 & - \\
\hline$y$-Terpinene & 1.4878 & - \\
\hline Carveol, dihidro & 1.5082 & 2.496 \\
\hline d-Camphene & 1.5382 & - \\
\hline Cyclofenchene & 1.5667 & - \\
\hline Isoanethole & 1.6402 & 2.775 \\
\hline Caryophyllene oxide & 1.8256 & - \\
\hline Linalool & 2.1405 & 3.503 \\
\hline Anisole, & 2.1673 & - \\
\hline Retinol & 2.2265 & 3.760 \\
\hline Anisole, o-(l-ethylvinyl & 2.2432 & - \\
\hline B-Caryophyllene & 2.2873 & 3.819 \\
\hline Champaca camphor & 2.5565 & 4.169 \\
\hline a-Caryophyllene alcohol & 2.5913 & 4.320 \\
\hline Vertioiol & 2.6156 & 4.433 \\
\hline o-Isoeugenol & 2.6938 & 4.663 \\
\hline Engenol & 2.8171 & 4.746 \\
\hline 2,4-Dimethoxy-3-methylbenzaldehyde & 2.8675 & 4.840 \\
\hline Anisyl acetate & 2.9241 & 4.886 \\
\hline Vitexin & 2.9521 & - \\
\hline Isoretinene & 3.0846 & 5.244 \\
\hline Asterol & 3.1682 & 5.509 \\
\hline Benzyl alcohol,a-ethyl-p-methoxy & 3.3285 & - \\
\hline Retinamide, N-(4-hydroxyphenyl & 3.4121 & - \\
\hline Dienestrol & 3.6687 & - \\
\hline 3,4-Dimethoxycinnamic acid & 3.8699 & - \\
\hline Diethylstibestrol & 3.8905 & - \\
\hline Fisetin & 3.9079 & - \\
\hline Sinapic acid & 3.9740 & - \\
\hline Coniferyl aldehyae & 4.0147 & 6.652 \\
\hline (-)-a-Tocopherol & 4.0778 & - \\
\hline Resveratrol & 4.1495 & - \\
\hline Vinpocetine & 4.1786 & - \\
\hline Cannabinol & 4.2704 & - \\
\hline Longlpinocarvone & - & 3.581 \\
\hline 9-cis-Retinal & - & 3.917 \\
\hline
\end{tabular}




\begin{tabular}{|l|c|c|}
\hline Caryophllene oxide & - & 4.051 \\
Champaca camphor & - & 4.250 \\
Linolenin l-mono & - & 4.480 \\
Vitexin & - & 4.886 \\
Retinyl propionate & - & 5.364 \\
\hline
\end{tabular}

throughout the whole experiment. The bird was provided with programmable adequate ventilation, where the air is removed from the house by means of exhaust fans. The experiment was started at 26 weeks of age and terminated at 47 weeks of age.

Preparation of Anise and Caraway seeds powder, experimental diets and bioaactive chemical analysis.

One batch $50 \mathrm{~kg}$ of both fresh Anise and Caraway seeds were obtained from the local market. Seeds dried naturally in a sunny then they were ground using a mixer and stored in bags at ambient temperature $\left(27-30^{\circ} \mathrm{C}\right)$ before being supplemented into diets. The proximate chemical compositions and bio-active components are shown in Tables 2 according to method of AOAC (1994). The analysis of bio-active components was carried out using a GC (Agilent technologies 7890A) interfaced with a mass-selective detector (MSD, Agilent 7000 equipped with a polar Agilent HP-5ms (5\%-phenyl methyl poly siloxane) capillary column (30 mx $0.25 \mathrm{~mm}$ i.d. and $0.25 \mathrm{um}$ film thickness). The carrier gas was helium with the linear velocity of $1 \mathrm{ml} / \mathrm{min}$.

The injector and detector temperature were $200^{\circ} \mathrm{C}$ and $250^{\circ} \mathrm{C}$ respectively. Volume injected 1ul of the sample. The MS operating parameters were as follows: ionization potential $70 \mathrm{ev}$, interface temperature $250{ }^{\circ} \mathrm{C}$, and acquisition mass range 50-800.The identification of components was based on a comparison of their mass spectra and retention time with those of the authentic compounds and by computer matching with NIST and WILEY library as well as by comparison of the fragmentation pattern of the mass spectral data with those reported in the literature (Santana et al., 2013).

\section{Data recorded:}

\section{Laying performance:}

The birds were weighed at the start and at the end of the experiment. Body weight changes were calculated as the difference between the initial and final body weight. However, feed intake was recorded and calculated as the decrease, in grams, of feed over 7 days, divided by the number of bird days. Feed conversion ratio (FCR) was calculated as the amount of feed consumed ( $\mathrm{g}$ ) required to produce a unit $(\mathrm{g})$ of egg mass (feed conversion $=\mathrm{g}$ feed $/ \mathrm{g}$ egg). 
Also, eggs were daily collected and the egg number was calculated on a hen-day basis. Egg weight $(\mathrm{EW})$ and egg number were daily recorded to calculate the egg mass (egg number $\times$ egg weight). All production variables were determined on a replicate basis.

\section{Blood biochemical parameters:}

At the end of experiment 3 birds were randomly selected from each treatment after fasting for $12 \mathrm{~h}$ for blood samples. Approximately $5.0 \mathrm{~mL}$ of fresh blood were taken from the jugular vein using a $5 \mathrm{~mL}$ syringe fitted with a 24-gauge sterile hypodermic needle. Each blood sample from each individual was drawn in tubes which containing using Ethylenediamine-tetraacetic acid (EDTA) as an anticoagulant and then centrifuged at $3500 \mathrm{rpm}$ for $15 \mathrm{~min}$ to obtain plasma. The following biochemical parameters levels were determined spectrophoto-metrically using commercial diagnostic kits provided from Bio diagnostic Company (Giza, Egypt). Plasma was separated and used for determination total protein (Gornal et al., 1949), albumin (Doumas et al., 1971) total lipids (Zollner and Kirsch, 1962), triglycerides (Richmond, 1973), cholesterol (Richmond, 1973), glucose (Trinder, 1969), and total antioxidant capacity (TAC) (Koracevic et al., 2001). The values of globulins were obtained by subtracting the values of albumin from the corresponding values of total protein. Also, A/G ratio was obtained by dividing the values of albumin / globulin.

\section{Egg quality traits:}

Some of egg quality traits were done on the same day once all samples were collected. At the end of experiment (47 weeks of age), 15 eggs was randomly collected from each group (3 eggs per replicate) to assess interior and exterior egg quality parameters. Freshly laid eggs were individually weighed on an electric balance, accurate to $0.01 \mathrm{~g}$, the egg length and width were determined before breaking. Shell thickness was determined, where the mean value of measurements at 3 locations on the egg (air cell, equator and sharp end) by using a dial gauge micrometer according to Yannakopoulos and Tserveeni-Gousi (1986). Albumen index, yolk index, Haugh unit, were measured as internal egg quality parameters. Egg shape index $(\%)$ was recorded according to Romanoff and Romanoff (1949). Egg yolk visual color was measured by matching the yolk with one of the 15 bands of the Roche yolk color fan. Haugh units, a measure of the height of the albumen of eggs broken out on a flat surface were measured using a tripod micrometer. Haugh units were calculated as follows according to the formula proposed by Cotta (1997): 


$$
\mathrm{HU}=100 \log (\mathrm{h}-1.7 \mathrm{w}+7.6) \text {, }
$$

Where, $\mathrm{HU}=$ Haugh units, $\mathrm{h}=$ Albumen height $(\mathrm{mm})$ and $\mathrm{w}=$ Egg weight $(\mathrm{g})$.

\section{Yolk extraction and cholesterol determination:}

At the same time of conducting egg quality traits, yolk of eggs was taken from each group alone for determination the cholesterol content (mg of cholesterol /g of egg yolk). For yolk fat extraction one gram of yolk was placed into a centrifuge tube, homogenized with $15 \mathrm{ml}$ of polar solvents chloroform: methanol mixture, 2:1 (v/v), vortexed, filtered and evaporated according to Folch et al. (1957), as modified by Washburn and Nix (1974). Cholesterol concentration was determined by ultraviolet spectrophotometer using commercial kits according to the methods described by Kaya et al. (2001).

\section{Immune response against Newcastle disease (ND) and total count of aerobic bacterial (CFU/g):}

In order to measure the antibody titer response against Newcastle disease virus (NDV), blood samples were collected from jugular vein at different periods of egg production for Haemagglutination Inhibition (HI) test (OIE, 2012) to determine the antibody titer response. Titers were expressed as the $\log ^{2}$ of the reciprocal of the highest dilution giving visible Haemagglutination. The immunoglobulin's $\mathrm{G}(\operatorname{IgG}), \mathrm{M}(\mathrm{IgM})$ and $\mathrm{A}(\operatorname{IgA})$ were determined according to Granfors (1979). To measure the total count of aerobic bacterial digesta from 21 birds ( 3 birds per treatment) were collected and used for microbial assays using spread plate technique method described by Quinn et al. (1994). Microbial level were expressed as colony forming unit $\left(\mathrm{CFU} \mathrm{g}^{-1}\right)$ per gram of sample.

\section{Data analysis:}

Data analysis according to Snedecor and Cochran (1982) was performed using General Linear Models (GLM) procedure of SPSS software program package) Version 16 (SPSS, 2010). All data were analyzed based on a completely randomized design using one way ANOVA. All percentages were first transformed to arcsine to approximate normal distribution before ANOVA. Data were presented as means \pm SEM. When the treatment effect was significant at $\mathrm{P} \leq 0.05$, Duncan test was applied to identify significant differences among groups. All obtained data were analyzed by using the following model Equation;

Where, $Y_{\mathrm{ij}}=$ is the analyzed measurement

$$
\mathrm{Y}_{\mathrm{ij}}=\mathrm{u}+\mathrm{S}_{\mathrm{i}}+\mathrm{e}_{\mathrm{ij}}
$$

$\mathrm{u}=$ Overall mean, $\mathrm{S}_{\mathrm{i}}=$ Effect of experimental diets $(\mathrm{i}=1$...to 7$), \mathrm{e}_{\mathrm{ij}}=$ Experimental error. 
Duncan's multiple range test was used to detect any significant differences among the experimental means (Duncan, 1955).

\section{RESULTS}

\section{Proximate chemical analysis and bio-active components:}

The results of proximate and phytochemical compositions of Anise and Caraway seeds powder are shown in Table 2. The result of proximate chemical analysis showed that the moisture content of Anise and Caraway were found to be 10.40 and $9.78 \%$ respectively, where Anise seed recorded slightly higher value than those recorded for Caraway. However, Caraway had an appreciable higher values of crude protein $(\mathrm{CP})$ content $(20.03 \%)$, ash $(11.61 \%)$, and crude fiber $(20.16 \%)$ than those values recorded for Anise (17.40, 10.14 and 14.7\%) respectively. While, Caraway had low content of ether extract $(20.96 \%)$ than those recorded for Anise $(27.09 \%)$. On the other hand, results presented in the same Table indicated that both Anise and Caraway have variable bio-active components. The Anise has higher content of bio-active components i.e., cannabinol, vinpocetine, resveratrol, a-tocopherol and coniferyl aldehyae than other bio-active constituents present in the Anise. However, Caraway contains higher value of bioactive constituents including coniferyl aldehyae, retinyl propionate, asterol, vitexin than those other active constituents observed in the Caraway.

\section{Effects of anise and caraway supplementation on: \\ 1-Laying performance:}

Results of laying performance, as impacted by Anise and Caraway powder are clarified in Table 3. From the present results it is observed that at the end of the experiment (47 weeks of age), laying hens fed diets supplemented with 0.3 and $0.2 \%$ Caraway tended to have a higher body weight gain than those values recorded for other levels of both seeds or control group. However, egg production significantly $(\mathrm{P}<0.05)$ improved for birds fed diet supplemented with $0.1 \%$ Caraway seed powder compared with other levels or control group. Also, egg weight, egg mass and feed intake showed significantly higher $(\mathrm{P}<$ 0.05 ) values for birds fed diets supplemented with different levels of both Anise and Caraway compared with the control group. On the other hand, the values of feed conversion ratio exhibited the best records for groups fed different levels of Anise and Caraway compared with the control group. From the results it is very interesting to note that dietary inclusion of Anise and Caraway caused a significant improvement in all laying performance along the experimental period. 


\section{2-Blood biochemical parameters:}

The effect of Anise and Caraway seeds powder on blood biochemical parameters measured at the end of the experiment have been presented in Table 4. As can be seen, the addition of Anise and Caraway seeds powder significantly increased protein profile including total protein, albumin and globulin of the blood compared with the control group $(\mathrm{P}<0.05)$. While, the values of $\mathrm{A} / \mathrm{G}$ ratio showed the converse trend, where the highest records observed for birds present in control group or those birds fed $0.1 \%$ Anise seed powder compared with other levels of both seeds. However, the Anise and Caraway supplementation in the diets led to a significant $(\mathrm{p}<0.05)$ decrease in lipid profile including total lipids, triglyceride and cholesterol concentration as compared with the control group. Clearly, data recorded of glucose concentration indicated that incorporation of Anise in laying hen diets at $0.3 \%$ showed the highest value; while groups fed 0.1 and $0.2 \%$ Caraway have the lowest concentration compared with other groups. Concerning the values of total antioxidant capacity (TAC), the analysis of variance indicated that laying hens fed diet inclusion $0.3 \%$ Caraway showed high value , followed groups fed 0.1 , 0.2 Caraway and $0.3,0.2$ and $0.1 \%$ Anise or control groups. Clearly observed from these data that birds fed diet supplemented with different levels of Caraway and Anise seeds powder positively decreased lipid profile.

\section{3-Egg quality traits and yolk cholesterol contents:}

The effect of dietary treatments on egg quality traits and yolk cholesterol contents are shown in Table 5. It is observed that incorporation different levels of Anise and Caraway seeds powder in laying hen diets had no significant effect on egg shape index and shell thickness. While, there was a significant $(\mathrm{P}<0.05)$ differences observed among the experimental groups concerning albumin index, yolk index, Haugh unit and yolk color. The analysis of variance showed that yolk color pigmentation significantly $(\mathrm{P}<0.05)$ improved due to incorporation of both Anise and Caraway seeds powder as compared with the control group. On the other hand, we find that the great effect of both seeds is the great ability to reduce the level of cholesterol concentrations in the egg yolk compared with the control group $(\mathrm{P}<0.05)$, where the lowest levels detected observed for hens fed $0.3 \%$ Caraway seed powder.

\section{4-Immune response and total count aerobic bacteria:}

To evaluate the effects of dietary supplementation of Anise and Caraway seeds powder on the immune response and total count aerobic bacteria data presented in Table 6 , the analysis of variance indicated that there was a 
Table (6): Effect of supplementation Anise and Caraway seeds powder on immunity response ( $\log ^{2}$ value) and total count aerobic bacteria $(\mathrm{CFU} / \mathrm{g})$ for whole experimental period.

\begin{tabular}{|c|c|c|c|c|c|}
\hline \multirow{3}{*}{ Treatments } & \multicolumn{5}{|c|}{ Items } \\
\hline & \multirow{2}{*}{$\begin{array}{c}\text { Immunity } \\
\text { response } \\
\text { (HI Titer } \\
\log ^{-2} \text { value } \\
\text { ) }\end{array}$} & \multicolumn{3}{|c|}{$\begin{array}{c}\text { Immunoglobulin for } \\
\text { whole period } \\
(\mathrm{mg} / \mathrm{dL})\end{array}$} & \multirow{2}{*}{ 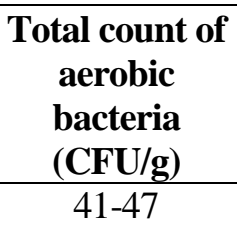 } \\
\hline & & $\overline{I g G}$ & IgM & $\operatorname{IgA}$ & \\
\hline $\mathrm{C}(0.0 \%)$ & $77.52^{\mathrm{c}}$ & $1.74^{\mathrm{d}}$ & $10.52^{\mathrm{e}}$ & $77.63^{\mathrm{e}}$ & $7.20^{\mathrm{a}}$ \\
\hline $\mathrm{C}+0.1 \% \mathrm{ASP}$ & $8.19^{\mathrm{b}}$ & $1.92^{\mathrm{c}}$ & $10.81^{\mathrm{d}}$ & $80.36^{d}$ & $6.27^{\mathrm{b}}$ \\
\hline $\mathrm{C}+0.2 \%$ ASP & $8.37^{\mathrm{b}}$ & $1.92^{\mathrm{c}}$ & $11.29^{\mathrm{c}}$ & $83.41^{\mathrm{c}}$ & $5.44^{\mathrm{c}}$ \\
\hline $\mathrm{C}+0.3 \%$ ASP & $8.66^{\mathrm{a}}$ & $2.14^{\mathrm{b}}$ & $11.75^{\mathrm{b}}$ & $84.63^{\mathrm{b}}$ & $5.15^{\mathrm{c}}$ \\
\hline $\mathrm{C}+0.1 \% \mathrm{CSP}$ & $8.92^{\mathrm{a}}$ & $2.29^{\mathrm{a}}$ & $12.83^{\mathrm{a}}$ & $85.44^{\mathrm{ab}}$ & $5.18^{\mathrm{c}}$ \\
\hline $\mathrm{C}+0.2 \% \mathrm{CSP}$ & $8.88^{\mathrm{a}}$ & $2.34^{\mathrm{a}}$ & $12.87^{\mathrm{a}}$ & $86.48^{\mathrm{a}}$ & $4.48^{\mathrm{d}}$ \\
\hline $\mathrm{C}+0.3 \% \mathrm{CSP}$ & $8.87^{\mathrm{a}}$ & $2.34^{\mathrm{a}}$ & $12.92^{\mathrm{a}}$ & $86.21^{\mathrm{a}}$ & $4.11^{\mathrm{d}}$ \\
\hline SEM* & 0.11 & 0.05 & 0.21 & 0.69 & 0.22 \\
\hline P-value ${ }^{* * *}$ & 268.886 & 47.539 & 311.715 & 80.961 & 20.229 \\
\hline Sig. test & $*$ & $*$ & $*$ & $*$ & $*$ \\
\hline
\end{tabular}

gradual increase in serum antibody titer response, which was statistically significant $(\mathrm{P}<0.05)$ measured at the end of experiment. Also, immunoglobulin classes (IgG, IgM and $\operatorname{IgA}$ ) showed the same trend, where Anise and Caraway supplementation significantly $(\mathrm{P}<0.05)$ increased the values of $\operatorname{IgG}, \operatorname{IgM}$ and IgA recorded at the end of experiment. On the other hand, data revealed that total count $f$ aerobic bacteria showed the converse opposite trend, where laying hens fed diet inclusion different levels of Anise and Caraway seed powered recorded lower value than those values observed for the control group $(\mathrm{P}<0.05)$.

\section{DISSCUSION}

\section{Proximate chemical analysis and bio-active components:}

Interestingly, the chemical composition is the first step to evaluate the nutritive and medicinal value for any feedstuff. The objective of this study was to investigate the use of Anise and Caraway seeds as a feed additive in laying chicken nutrition. The result of proximate analysis showed that the $\mathrm{CP}$, 
ash, $\mathrm{CF}$, and DM contents of Caraway recorded slightly higher values than those recorded for Anise. While, Anise has higher content of EE and moisture contents than those values observed for Caraway. The variation in chemical analysis may be due to soil nutrients and environmental factors which have effects on the nutrients availabilities for plants (Adewole et al., 2017). In this context, Kaki et al. (2018) noted that the proximate chemical analysis of crushed Caraway seed of DM, OM, CP, CF, EE, ash, NDF and ADF were 93.64, 83.84, 19.25, 28.70, 3.81, 11.69, 67.64 and 40.13 \%, respectively. However, Zidan et al. (2019) found that the proximate chemical composition of star Anise $(\mathrm{mg} / \mathrm{g}$ ) was determined in terms of protein, fat, fiber, carbohydrates, ash, dry matter, where the contents were $6.41,3.93,27.74,58.56,3.36$ and $86.65 \%$ respectively.

However, Phytochemicals or bio-active components are of benefit to health and play an active role in the management of some diseases. Therefore, phytochemicals referred to phytogenic, which are natural bioactive compounds that are derived from plants and incorporated into animal feed to enhance productivity (Gadde et al., 2017). According to Franz et al. (2005) indicated that Anise seeds contain 2 - 6\% essential oil and also phenolic acids, flavonol and flavone glycosides. The predominant constituent of the essential oil is transanethole (80 - 95\% of total oil), a powerful flavouring which belongs to the phytoestrogens.

The present study indicates that Anise contains a number of bioactive compounds, more than detected in Caraway, where bioactive components including coniferyl aldehyae, a-tocopherol, resveratrol, vinpocetine and cannabinol are the most active substances in terms of their percentage. While, Caraway contains bio-active components i.e., isoretinene, asterol, and retinyl propionate with greater proportions than the rest of the other active components. In this context, Ciftci et al. (2005) indicated that Anise seeds have a number of active compounds, particularly volatile oil (1-4\%), which consists of largely trans-anethol (70- 90\%) with estragole (methylchavicol), Anisealdehyde, bcaryophlline, Anise ketone (methyloxyphenylacetone) and the polymers of anethole. Also, Sedláková et al. (2003) showed that Caraway seeds contain 19\% essential oils consisting of more than 30 compounds, where the carvone and limonene were account the main portions. In addition, Abou El-Soud et al. (2014) found that the essential oil compounds of Caraway were included (\%) $\alpha$ Pinene 0.3, Camphene0.2, $\beta$-Pinene 0.1, $\beta$-Myrcene 0.1, Limonene 5.1, $\gamma$ Terpinene 12.6, $\beta$-Ocimene 0.1, p-Cymene 0.1,Terpinolene 0.1, limonene oxide 0.1, Camphor 0.2,Linalool 0.7, Linalyl acetate 0.3, Terpinene-4-ol 0.1, $\beta$ Caryophyllene, Dihydrocarvone $0.2, \alpha$-Terpineol 0.1 ,Germacrene-D 0.1 , 
Carvone 70.1, $\beta$ - Selinene 0.2, $\alpha$-Farnesene 0.4, Citronellol 0.1, $\delta$-Cadinene 0.3, $\gamma$-Cadinene 0.5, Cuminaldhyde 0.1, Nerol 0.2, Trans-carveol 0.1,Nonadecane 0.1, Spathulenol 0.3, Eugenol 0.2, Thymol 0.5and Carvacrol 0.2 . Also, Neveen et al. (2014) showed that the major components of Caraway essential oil were Carvone (70.1\%) followed by $\gamma$-Terpinene $(12.6 \%)$ and Limonene $(5.5 \%)$ in addition to some minor compounds including Linalool $(0.7 \%)$, Thymol $(0.5 \%), \gamma$ -Cadinene (0.5\%), $\alpha$ - Farnesene $(0.4 \%), \delta$ - Cadinene $(0.4 \%)$.

\section{Effects of anise and caraway supplementation on: 1-Laying performance:}

The present results of diet chemical analysis (Table 2) were formulated to cover the laying hens' diets (16.14\% CP and $2751 \mathrm{kcal} \mathrm{ME} / \mathrm{kg} \mathrm{DM}$ feed) as reported by (NRC 1994). Data presented in this study showed that final body weight and change in weight (gain) significantly improved at the end of experiment by feeding diets supplemented with Anise and Caraway seeds powder. This improvement might be due to improved digestion and absorption of diet nutrients by increasing enzymes and saliva secretion and subsequently improved digestion processes (Suganya et al., 2016).

Therefore, the active ingredient present in seeds has positive effects on nutrient digestibility and increasing activities of pancreatic lipase and amylase (Ramakrishna et al., 2003). This observation is confirmed by Kassie (2008) found that the star Anise may be widely used for growth promoting in poultry as a result of stimulating digestion and antimicrobial effects. Also, Ciftci et al. (2005) found that Anise essential oil dietary supplementation at $400 \mathrm{mg} / \mathrm{kg}$ diet in broilers, resulted in significant better body weight gain. The result of this study demonstrated that egg production, egg weight and egg mass tended to be significantly increased, due to inclusion Anise and Caraway seeds powder. This improvement may attributed to the synergetic effect of bioactive chemical ingredients present in these seeds, which modulating gut microbiota, enhancing nutrient digestibility and absorption, and improving ovarian characteristics resulted in better health status and subsequent improved laying performance (Boka et al., 2014). The result of Yu et al. (2018) demonstrated that egg mass, egg weight and feed intake increased by the addition of star Anise oil in the laying hens diets from 200 to $600 \mathrm{mg} / \mathrm{kg}$. This finding is compatible with Yang et al. (2017) found that laying hens supplemented with star Anise, salvia miltiorrhiza and ginger root improved laying rate and egg mass of Hy-Line brown laying hens at 40 weeks of age. Also results of this study indicated that birds fed diets inclusion Anise and Caraway significantly improved feed intake and feed conversion ratio. The increased feed intake due to supplementation 
Anise and Caraway is likely attribute to a stimulating effect of appetite as a result of aromatic flavour (Wang et al., 2011). In this connection, Al-Kassie (2008) showed that broilers fed on a diet containing 1\% Anise had higher feed intake than those recorded for the control group. Also, Bayram et al. (2007) showed that feed intake and feed conversion ratio was improved for broiler chickens when fed diets supplemented with star Anise seed at $40 \mathrm{~g} / \mathrm{kg}$. In general, Windisch et al., (2008) reported that feed additives derived from plants, which called phytogenics or phytobiotics can be included in animals' diets to improve their productivity and the properties of the resulting feed and animal products.

\section{2- Biochemical blood parameters:}

Interestingly, biochemical blood parameters are usually related to health status, where these parameters are vital indicators of the nutritional and physiological status of birds. It is observed from obtained data that blood biochemistry profiles were within the expected range, and no signs of toxicity or diseases due to experimental diets. It is notice that blood protein profiles significantly affected by the dietary supplementation reflecting no injury of liver by the addition of both seeds. This effect may attributed to beneficial effects of bioactive components such as flavonoids, phenolic compounds and polyphenols present in both seeds that play a vital role in the preserving of liver cells, (Amit Roy et al., 2014).

In addition, the increase of protein profile due to inclusion Anise and Caraway reflect better hepatoprotective activity of seeds may be owing to the free radical scavenging (antioxidant) properties of its components. It was noted from this study that the use of Anise or Caraway seed powder as additives in laying chicken diets is safe when used by $0.3 \%$ without any adverse side effects on liver function. In this context Soltan et al. (2008) found that Anise supplementation at $0.5 \mathrm{~g} / \mathrm{kg}$ of broiler diet increased serum albumin, A/G ratio, while decreased globulin concentration. Also, Al-Shammari et al. (2017) found that when supplemented Anise seed powder at 0,500, 750, and 1000mg/L to the drinking water in broiler significantly improved albumin and globulin compared with the control group. In another study, Jafari (2011) showed that using Caraway powder in diet of Japanese quail at 1.0\%, 1.5\% and 2.0 had a significant effect on blood biochemical parameters. On the other hand, blood lipids profile depend on the conditions of breeding, nutrition and sexual activity (Itoh et al., 1998). Therefore, in the current study, the addition of Anise and Caraway powder have vital roles in reducing lipid profiles including total lipids, cholesterol and triglyceride compared with the control group. This may be attributed mainly to the inhibitory effects of phytogenic bioactive components on hepatic 3-hydroxy-3- 
methylglutaryl coenzyme A reductase activity (a critical enzyme in cholesterol biosynthesis), thereby reducing cholesterol synthesis (Crowell, 1999) or by decreasing its fractional reabsorption from the small intestine (Brunton, 1999). Also, the reduction of blood cholesterol could be contributed in some cases to the reduction in some hormones secreted by the cortex of adrenal glands, which in turn causes the reduction in the secretion of fatty acids from adipose tissues or the reduction of fat oxidation that lead to the reduction of level of fatty acids including cholesterol and triglyceride (Ganong, 2005). This finding is consistent with Christaki et al. (2011) showed that total cholesterol and triglycerides considerably lowered in Japanese quails when fed diets supplemented with ground Anise seed at $10 \mathrm{~g} / \mathrm{kg}$ and $20 \mathrm{~g} / \mathrm{kg}$. Also, Khajeali et al. (2013) indicated that adding 1, 1.5 and $2 \%$ of Caraway to broiler diets led to a decrease of triglyceride levels in birds compared to the control group. Also, Ali et al. (2007) reported that the addition of Anise in laying gen diet decreased the levels of serum triglyceride and total lipids.

However, results showed that total glucose recorded the highest value for birds fed diets containing 0.3 Anise seed powder, while the lowest values observed for birds fed diets inclusion 0.1 and $0.2 \%$ Caraway. This finding are disagree with results obtained by Tabanca et al. (2003) found that Anise supplementation at 0.25 and $0.5 \mathrm{~g} / \mathrm{kg}$ of broiler diet reduced serum levels of glucose when compared with the control group. On the other hand, Kucukkurt et al. (2009) indicated that plasma glucose of laying quails insignificantly affected when fed diet inclusion Anise seeds at 0, 10, 20, 30, 40, and $50 \mathrm{~g} / \mathrm{kg}$. However, the statistical analysis showed that the inclusion of both Anise and Caraway seeds powder in diets are beneficial in increasing total antioxidant capacity (TAC) especially with group fed diet inclusion $0.3 \%$ Caraway, this may attributed to the ability of Caraway to exhibited high antioxidant activity which has been attributed largely to the presence of monoterpene alcohols, linalool, carvacrol, carvone, flavonoids and other polyphenolic compounds (Najda et al., 2008), and neutralize free radicals which reduce plasma malondialdehyde. In addition, Anise seed possess a potent antioxidant activity that may be attributed to many polyphenol compounds have been detected in extracts from different Anise species and anethole (Kang et al., 2013). This finding is agree with Hoda et al. (2015) showed that the activity of MDA was decreased, and the activities of SOD, GSH-Px, and CAT were significantly high in the rat groups administered black Caraway oil 5, 10, and $20 \mathrm{mg} \mathrm{kg}-1$ body weight, respectively. Also, Ding et al. (2017) found that supplementation of star Anise and its essential oil increased activities of super 
dismutase, glutathione peroxidase, and catalase but decreased content of malondialdehyde in the serum of broilers at $21 \mathrm{~d}$ and $42 \mathrm{~d}$ of age of broiler.

\section{3- Egg quality traits and yolk cholesterol contents.}

The improvement in egg quality is of paramount importance in the field of production and management (Mahmoud et al., 2010). Therefore, there is a dearth of literature available concerning the beneficial effects of Anise or Caraway addition on egg quality traits of laying diets. It is cleared that, egg weight, yolk color, albumin index, and Haugh unit significantly improved by the inclusion of Anise and Caraway in laying diets. Interestingly, the increased of egg yolk colour in this study indicated more pigmentation of birds fed diets inclusion Anise and Caraway.

The enhanced pigmentation by Anise and Caraway supplementation is likely attributed to natural pigments in Anise and Caraway that can be absorbed and transferred into the egg yolk and to consumption of zeaxanthin, lutein, alphacarotene, beta-carotene, and carotenoids present in seeds (Hammershoj et al., 2010). In addition, it is well recognised that egg yolk colour is important to consumers and is one of the main parameters by which the quality of an egg is judged (Hammershoj and Steenfeldt, 2005). In this connection, Christaki et al. (2011) found that the egg yolk colour parameter was significantly increased by the dietary addition of Anise seed at $10 \mathrm{~g} / \mathrm{kg}$ or $20 \mathrm{~g} / \mathrm{kg}$ but did not modify the $\mathrm{L}^{*}$ (lightness) and $\mathrm{b}^{*}$ (yellowness) parameter of egg yolk colour of laying Japanese quail. On the other hand, egg yolk cholesterol content was tended to decrease significantly decreased due to feeding hens on diets containing different levels of Anise and Caraway compared with the control group. The decrease in cholesterol content, this may be related to the active components (thyme and carvacrol) present in seeds, where these components reduce the liver enzyme activity of 3-hydroxy-3-methylglutaryl coenzyme A reductase (HMG-CoA reductase), which is a key enzyme in cholesterol synthesis (Abdulkarimi et al., 2011). Also the decrease of cholesterol content of eggs for birds fed diets inclusion Caraway and Anise may be due to the reduction of serum total cholesterol and triglycerides concentration in blood compared to the control group (Jafari, 2011).

\section{4- Immunity response and total count aerobic bacteria.}

In the poultry industry, it is important to stimulate the immune system to reduce or prevent infectious diseases. Many factors like failure of vaccination and inhibition of antibiotics can induce immunodeficiency. Therefore, the usage of immune enhancers is a key solution to improving immunity and reducing 
susceptibility to infectious diseases in poultry farms. The precise mechanism of phytogenic on immunomodulation is still not fully clear. The immune response was mediated by employing HI test to detect the antibody titer against New Castle Disease are presented in Table 6. It is observed the addition of Anise and Caraway to layer diets may improve the immune system due to the increase in immunoglobulin concentrations (IgG, $\operatorname{IgA}$ and $\operatorname{IgM}$ ). It has been reported that under the practical conditions, it is quite common to vaccinate layer chicken at different ages against ND to provide the flocks by protective immunity as maternal immunity wears. Clearly, the results obtained from the study can explain the nutritional and biological effects of examined treatments on immune response. Compared with the control group the values of $\operatorname{IgG}, \operatorname{IgM}$ and $\operatorname{IgA}$ were elevated in birds fed diets supplemented with Anise and Caraway seeds powder. It is interesting to note that Caraway seed which is richness in polyunsaturated fatty acids, which help to produce prostaglandin E1. Prostaglandin E1 has so many functions such as in relation to the immune system.

This improvement in immunity may be due to Anise and Caraway are rich in flavonoids act as antioxidants and may enhance immune function (Acamovic and Brooker, 2005). In addition phytochemicals also exert their action through immunomodulatory effects such as increased proliferation of immune cells, modulation of cytokines, and increased antibody titers (Lee et al., 2017). Also, it is observed that many different active components present in these seeds has significantly enhanced immune response. Theses findings are consistent with Alhajj et al. (2015) reported that inclusion of $6 \mathrm{~g}$ of Anise seed in broiler diet diet showed higher antibody titer against Newcastle disease virus and infectious bronchitis. Also, Khajeali et al. (2012) showed that antibodies titers against New Castle Vaccine was significantly increased when broilers was fed with a diet contains high level of Caraway. Also, Mahmood et al. (2014) reported that Aniseed addition to basal diet at the rate of $0.5 \mathrm{~g} / \mathrm{kg}$ and $1.0 \mathrm{~g} / \mathrm{kg}$ of feed had best immunomodulatory activity both for humoral and cellular immune response. In this regard, Al-Beitawi et al. (2009) found that the use of Anise seeds in broiler chickens resulted in improved antibody titers against NDV.

However, results concerning total count of aerobic bacteria indicated that there was a significant decrease in values for birds fed diet inclusion different levels of Anise and Caraway compared with the control group. This attributed to the appropriate amount of cumin aldehyde can explain the antibacterial effects for Caraway. In addition active components such as pinene and sabinene present in Caraway has antibacterial effects (Gachkar et al., 2007). In addition, the antimicrobial activity of Anise may be attributed to their phenolic contents since 
numerous phytochemical studies indicated the presence of noticeable amounts of phenolic compounds in Anise is considered a natural anti-bacterial (Martins et al., 2016). In this context Proestos et al. (2006) found phenolic compounds present in Anise act as antimicrobial agents via several mechanisms including the disruption of microbial membranes. This could be considered another reason of improving the performance and immune status of the birds. This finding can be supported by the work done of Lillehoj et al. (2011) demonstrated that many of the healthpromoting activities of phytochemicals are mediated through their ability to enhance host defense against microbial infections. In general, many studies indicate that the main important function of the active substances in caraway is act as an antioxidant. Thus, it acts as an inhibitor of free radicals and protect tissues from damage (Crowell, 1999).

In conclusion, from these results, it could be concluded that Anise and Caraway seeds powder in the diet of laying hens as a safe and effective feed additive to improve laying performance and reduce total blood lipids and thus reduce cholesterol content in egg yolk.

\section{REFRENCES}

A. O. A. C., (1994). Association of Official Analytical Chemists, "Official Methods of Analysis $15^{\text {th }}$ Ed.Published by the A.O.A.C. Washington, DC., U.S. A.

Abdulkarimi, R.; M. Daneshyar and A. Aghazadeh (2011). Thyme (Thymus vulgaris) extract consumption darkens liver, lowers blood cholesterol, proportional liver and abdominal fat weights in broiler chickens. Italian J. of Anim. Sci., 10: 101-105.

Abou El-Soud, N. H.; N. A. El-Lithy; G. El-Saeed; M.S.Wahby ; M.Y. Khalil ; F. Morsy and N. Shaffie (2014). Reno protective effects of Caraway (Carumcarvi L.) essential oil in streptozotocin induced diabetic rats. J. of Appl. Pharma. Sci., 4(2):27-33.

Acamovic, T. and J.D. Brooker (2005) Biochemistry of plant secondary metabolites and their effects in animals. Proc. Nutr. Soc., 64 (3):403-412

Achilonu, M.; S. Karabo, A. Georgina, N. Kuben and M. Michael (2018). Phytochemical benefits of agroresidues as alternative nutritive dietary resource for pig and poultry farming. J. of Chem., ID 1035071, doi.org/10.1155/2018/1035071

Adewole, T.; Adetunji , B. Francis; L.M. Reckson and N. Bongani (2017). The biological activities of $\beta$-glucosidase, phosphatase and urease as soil quality indicators: a review. J. of Soil Sci. and Plant. Nutr., 17 (3): 794-807 
Al-Beitawi, N.A.; S.S. El-Ghousein and H.N. Abdullah (2009). Antibiotic growth promoters and Anise seeds in broiler diets. Jordan J. of Agric. Sci., 5(4):472-481

Al-hajj, M.S.; M. Alhobaishi; E.l. Ger; A.R. Nabi and S.I. Al-Mufarrej (2015). Immune responsiveness and performance of broiler chickens fed a diet supplemented with high levels of Chinese Star Anise fruit (Ifficiiimverum Hook. f). J. of Animal and Veter. Adv., 14 (2): 36-42.

Ali, M.N.; M.S. Hassan and F.A. Abd El-Ghany (2007). Effect of strain, type of natural antioxidant and sulphate ion on productive, physiological and hatching performance of native laying hens. Int. J. Poult. Sci., 6: 539-554

Al-Kassie, G.A.M. (2008). The effect of Anise and rosemary on the microbial balance in gastro intestinal tract for broiler chicks. Int. J. Poult. Sci., 7:610-612.

Al-Shammari, K.I.A.; J. Batkowska and M.M. Gryzińska (2017). Effect of various concentrations of an Anise seed powder (Pimpinella Anisum L.) supplement on selected hematological and biochemical parameters of broiler chickens. Brazilian J. of Poul. Sci., 19 (1): 041-046

Amit Roy, Dayananda Bhoumik, Ram Kumar Sahu and J. Dwivedi (2014). Medicinal Plants Used in Liver Protection. A Review. UK Journal of Pharmaceutical and Biosciences , 2(1), 23-33

Bayram, I., I.S. Cetingul, B. A Akkaya and C. Uyarlar (2007). Effect of Aniseed (Pimpinella anisum L.), on egg production, quality, cholesterol levels, hatching results and the antibody values in blood of laying quails (Coturnix coturnix japonica). Arch. Zootech., 10, 73-77.

Boka, J.; A. H. Mahdavi, A. H. Samie and R. Jahanian (2014). Effect of different levels of black cumin (Nigella sativa L.) on performance, intestinal Escherichia coli colonization and jejunal morphology in laying hens. J. of Animal Physi. and Animal Nutr., 98: 373-383

Bozkurt, M., F. Hippenstie; A.A.A. AbdelWareth; S.Kehraus; K. Küçükyilmaz and K.H. Südekum (2014). Effects of selected herbs and essential oils on performance, egg quality and some metabolic activities in laying hens - a review. Europ. Poult. Sci., 78. DOI: 10.1399/eps., 49

Brunton L.L. (1999). Agent Affecting Gastrointestinal Water Flux and Motility, Digestants and Motility. The Pharmacological Basis of Therpeutics. 8th Edition. Pergamon Press

Christaki, E.V.; E.M. Bonos and P.C. Florou-Paneri (2011). Use of Anise seed and/or $\alpha$-tocopheryl acetate in laying Japanese quail diets. South African J. of Anim. Sci., 41 (2): 126-133 
Ciftci, M.; T. Güler; B. Dalkiliç and O.N. Ertas (2005).The effect of Anise oil (Pimpinella anisum L.) on broiler performance .Inter. J. of Poul. Sci., 4:851-855.

Cotta, T. (1997). Reprodução da galinha e produção de ovos. Lavras: UFLAFAEPE, 81-92.

Crowell, P.L. (1999). Prevention and therapy of cancer by dietary monoterpenes. J. Nutr., 129: 775-778.

Ding,X.; C. W. Yang, and Z. B. Yang (2017). Effects of star Anise (Illicium verum Hook.f.), essential oil, and leavings on growth performance, serum, and liver antioxidant status of broiler chickens. J. Appl. Poult. Res., 26:459466

Doumas, B.T.; W. A. Watson and H. G. Biggs (1971). Albumin standards and the measurement of serum albumin with bromcresol green. Clin. Chim. Acta., 31(1):87-96

Duncan,D.B.(1955). Multiple range and multiple F test. Biometrics,11:1-42.

Folch, J.; M. Lees and G.H. Sloane-Stanley (1957). A simple method for the isolation and purification of total lipids from animal tissues. J. of Biol. Chem., 226: 497-509

Franz, C.; R. Bauer; R. Carle; D. Tedesco; A. Tubaro and K. Zitteri-Eglseer (2005). Study of the assessment of plants/herb extracts and their naturally or synthetically produced components as "additives" for use in animal production (CFT/EFSA/FEEDAP/2005/01).

Gachkar L, D. Yadegari; M.B. Rezaei; M. Taghizadeh; S.A. Astaneh and I. Rasooli (2007). Chemical and biological characteristics of Cuminum cyminum and Rosmarinus officinalis essential oils. Food Chem., 102 (3): 898- 904

Gadde, U., W.H. Kim; S.T.O.H and H.S. Lillehoj (2017). Alternatives to antibiotics for maximizing growth performance and feed efficiency in poultry: a review. Anim Health Res. Rev., 18:26-45

Ganong, W. F. (2005): Review of Medical Physiology. 16th ed., Alange Medical Book, pp. 336-338

Gheisar, M. M. and I. H. Kim, (2018). Phytobiotics in poultry and swine nutrition -a review. Italian J. of Anim. sci., 17 (1): 92-99

Gornall, A. G.; C. J. Bardawill and M. M. David (1949). Determination of serum proteins by means of the biuret reaction. J. Biol. Chem., 177(2):75166. 
Granfors, K. (1979). Measurement of immunoglobulin M (IgM), IgG, and IgA antibodies against Yersinia enterocolitica by enzyme-linked immunosorbent assay: persistence of serum antibodies during disease. J. Clin. Microbiol., 9 (3):336-41.

Hajati, H.; A. Hassanabadi and F.Ahmadian (2014). Application of medicinal plants in poultry nutrition. J. of Medicinal Plants and By-products, 1: 1-12.

Hammershøj, M. and S. Steenfeldt (2005). Effects of Blue Lupin (Lupinus angustifolius) in organic layer diets and supplementation with foraging material on egg production and some egg quality parameters. Poult. Sci., 84:723-733

Hammershoj, M.; U. Kidmose and S. Steenfeldt (2010). Deposition of carotenoids in egg yolk by short-term supplement of coloured carrot (Daucus carota) varieties as forage material for egg-laying hens. J. of the Sci. of Food and Agric., 90 (7): 1163-1171.

Hoda E.; H.Rajaian; S. Nazifi and M.Chahardahcherik (2015).The effect of Caraway (Carum carvi L.) on the blood antioxidant enzymes and lipid peroxidation in streptozotocin-induced diabetic rats. Comp. Clin .Pathol., 24(5): DOI 10.1007/s00580-014-2060-1

Itoh, N.; T. Makita, and M. Koiwa (1998). Characteristics of blood chemical parameters in male and female quails. J. of Vet. Medical Sci.,60: 1035-1037.

Jafari, B. (2011).Influence of Caraway on improve performance and blood parameters of Japanese quails. Annals of Biological Rese., 2 (6):474-478

Kaki, S.; M.M. Moeini; F. Hozhabriland Z. Nikousefat (2018).The Use of crushed Caraway (Carum carvi) and black seed (Nigella sativa) additives on growth performance, antioxidant status, Serum components and physiological responses of sanjabi lambs. Iranian J. of Appl. Anim. Sci., 8(3): 439-444

Kang, P., K.Y. Kim; H.S. Lee; S.S. Min and G.H. Seol (2013). Antiinflammatory effects of anethole in lipopolysaccharide-induced acute lung injury in mice. Life Sci., 93: 955-961.

Kassie, G. A. M. A.I. (2008). The effect of Anise and rosemary on broiler performance. Int. J. Poult. Sci., 7:243-245.

Kaya, S.; T. Keçeci and S. Haliloğlu (2001). Effects of zinc and vitamin A supplements on plasma levels of thyroid hormones, cholesterol, glucose and egg yolk cholesterol of laying hens. Res. Vet. Sci .,71:135-139. 
Khajeali, Y.; F. Kheiri; Y. Rahimian; M. Faghani and A. Namjo (2012). Effect of use different levels of Caraway (Carum carvi L.) powder on performance, some blood parameters and intestinal morphology on broiler chicks. World Appl. Sci. J., 24: 1044-1048

Khajeali, Y.; F. Kheiri; Y.Rahimian and M.Faghani (2013). Effect of use different levels of Caraway (Carum carvi L.) Powder on Performance, some blood parameters and intestinal morphology on broiler chicks. World Appl. Sci. J., 19: 1202-1207

Koracevic, D.; G. Koracevic; V. Djordjevic, S. Andrejevic, and V. Cosic (2001). Method for the measurement of antioxidant activity in human fluids. J. Clin. Pathol., 54:356-361

Kucukkurt, I., G. Avci; A. Eryavuz ; I. Bayram ; I.S. Cetingul ; A.B. Akkaya and C.Uyarlar (2009). Effects of supplementation of Aniseed (Pimpinella anisum L.) at various amounts to diets on lipid peroxidation, antioxidant activity and some biochemical parameters in laying quails (Coturnix coturnix japonica). Kocatepe Vet. J., 2 (1):1-5.

Laribi, B., K. Kouki ; A. Mougou and B. Marzouk (2010). Fatty acid and essential oil composition of three Tunisian Caraway (Carum carvi) seed ecotypes. J. Sci. Food Agric., 90, 391-396

Lee, M.T.; W.C. Lin; B.Yu and T.T. Lee (2017). Antioxidant capacity of phytochemicals and their potential effects on oxidative status in animals. A review. Asian-Australas J. Anim Sci., 30: 299-308

Lillehoj, H.S.; D.K. Kim; D.M. Bravo; and S.H. Lee (2011). Effects of dietary plant-derived phytonutrients on the genome-wide profiles and coccidiosis resistance in the broiler chickens. BMC Proc., 5:S34

Mahmoud KZ, Saad M, Gharaibeh H, Zakaria A, Amer M (2010). Garlic (Allium sativum) supplementation: influence on egg production, quality and yolk cholesterol level in laying hens. Aust J Anim Sci, 23:1503-1509

Mahmoud, K. Z.; M. Saad ; H. Gharaibeh ; A. Zakaria and M. Amer (2010). Garlic (Allium sativum) supplementation: influence on egg production, quality and yolk cholesterol level in laying hens. Aust. J. Anim Sci., 23:1503-1509

Martins, V.; L. Barros; C. Santos-Buelga and I.C.F.R. Ferreira (2016). Antioxidant potential of two Apiaceae plant extracts: a comparative study focused on the phenolic composition. Ind. Crops Prod., 79:188-194. 
Muahmmad S. M.; I. Hussain, M. F. Ahmad , A. Khan , R, Z. Abbas, and A.Rafiq (2014). Immunomodulatory effects of Pimpinella anisum $L$. (Aniseed) in broiler chicks against Newcastle Disease and infectious bursal disease viruses. Boletín Latinoamericanoy del Caribe de Plantas Medicinalesy Aromáticas, 13 (5): 458 - 465

Najda A., Dyduch J. and Brzozowski N. (2008). Flavonoid content and antioxidant activity of Caraway roots (Carum carvi). Veg. Crop. Res. Bull., 68, 127-133.

Neveen, H. Abou El-Soud ; A. Nabila A. El-Lithy , Gamila El-Saeed , Mohamed S. Wahby, Mona Y. Khalil, Fatma Morsy and Nermeen Shaffie(2014). Renoprotective effects of Caraway (Carum carvi L.) essential oil in streptozotocin induced diabetic rats. J. of Appl. Pharmaceutical Sci., 4 (2):027-033.

N.R.C(1994). Nutrient Requirements Of Poultry National. $9^{\text {th }}$ ed., Academy of Science, National Research Council. Washington, D. C. U.S.A.

OIE (2012). Newcastle Disease. Manual of diagnostic tests and vaccines for terrestrial animals. Chapter 2.3.14.http:/www.oie.int/ internationalstandard- etting /terrestrial-manual/access-online.

Proestos C, I.S.Boziaris; G.J.E. Nychas and M.Komaitis (2006). Analysis of flavonoids and phenolic acids in Greek aromatic plants: investigation of their antioxidant capacity and antimicrobial activity'. Food Chem.; 95:664-671.

Quinn, P.J.; M.E. Carter; B. Markey and G.R. Carter (1994). Clinical Veterinary Microbiology. $2^{\text {nd }}$ Edition Wolf/Mosby, London.

Ramakrishna, R.R.; K.Plateland and K. Srinivasan (2003). In vitro influence of species and spice active principles on digestive enzymes of rat pancreas and small intestine. Nahrung, 47: 408-412

Richmond, W. (1973) Preparation and properties of a cholesterol oxidase from Nocardia sp. and its application to the enzymatic assay of total cholesterol in serum. Clinical Chemistry, 19, 1350-1356.

Romanoff, A. L. and A. J. Romanoff (1949). In "The Avian Egg" John Wiley and Sons; Inc., New York, U.S.A.

Santana,P.M.; M. Miranda ; J. A. Payrol ; M. Silva ; V. Hernández and E. Peralta(2013). Gas chromatography-mass spectrometry study from the leaves fractions obtained of vernonanthura patens (Kunth) H. Rob. Inter. J.of Organic Chem., 2013, 3, 105-109 
Sedláková, J.; B. Kocourková, L. Lojková, and V. Kubáň(2003). Determination of essential oil content in Caraway (Carum carvi L.) species by means of supercritical fluid extraction. Plant Soil Environ., 49(6): 277-282

Seger, D.K. ; C.K Khalid Al-Salhie and Hatim A.J. AL-Shwill (2019). Effect of use of different levels of Caraway seed (carum carvi l.) powder on some physiological characteristics of Japanese quail. Plant Archives, 19 (1): 473-476

Snedecor, G. W., and W. G. Cochran (1982). Statistical Methods. 7th ed. The Iowa State University Press, Ames, IA

Soltan, M.A.; R.S. Shewita and M.I. El-Katcha (2008). Effect of dietary Anise seeds supplementation on growth performance, immune response, carcass traits and some blood parameters of broiler chickens. Inter. J. of Poultry Sci., 7 (11): 1078-1088

SPSS 16.0. (2010). Statistical Package in Social Science for Windows. Statistical innovation INC., Chicago, USA.

Suganya, T.; M. Varman ; H.J.H. Masjuki and S. Renganathan (2016). Macroalgae and microalgae as a potential source for commercial applications along with biofuels production: A bio refinery approach Renewable and Sustainable Energy Reviews, 55:909-941

Tabanca N; E. Bedir; N. Kirimer ; K.H. Baser ; S.I. Khan ; M.R. Jacob and I.A. Khan (2003). Antimicrobial compounds from Pimpinella species growing in Turkey. Planta Medica, 69:933-938.

Trinder, P. (1969). Determination of blood glucose using an oxidase-peroxidase system with a non-carcinogenic chromogen. J. Clin. Pathol., 22 (2):158-61

Wang, G. W., W. T. Hu, B. K. Huang and L. P. Qin (2011). Illicium verum: A review on its botany, traditional use, chemistry and pharmacology. $J$. Ethnopharmacol., 136:10-20.

Washburn, K. W. and D. J. Nix (1974). A rapid technique for extraction of yolk cholesterol. Poultry Sci., 53 : 1118-1122

Windisch,W.; K. Schedle, C. Plitzner and A. Kroismayr (2008). Use of phytogenic products as feed additives for swine and poultry. J. Anim. Sci., $86: 140-148$

Yang C. W.; X. Ding, X. Zhao, Y. X. Guo, A. L. Mu and Z. B. Yang (2017). Effects of star Anise (Illicium verum Hook. f.), salvia miltiorrhiza (Salvia miltiorrhiza Bge) and ginger root (Zingiber officinale Roscoe) on laying performance, antioxidant status and egg quality of laying hens. Europ. Poult.Sci., 81. DOI: 10.1399/eps.2017.183.

Yannakopoulos, A. L. and A. S. Tserveeni-Gousi (1986). Quality characteristics of quail eggs. Brt. Poultry Sci., 27:171-176. 
Yu, C.; Jiandong Wei, Chongwu Yang, Zaibin Yang, Weiren Yang and Shuzhen Jiang (2018). Effects of star Anise (Illicium verum Hook.f.) essential oil on laying performance and antioxidant status of laying hens. Poultry Sci., 97:3957-3966

Zidan,N.S.; M. Sakran; and U.A Farid (2019). Chemical composition of illicium verum (star anise) fruit. IAJPS, 06 (02): 4138-4144

Zöllner, N. and K.Kirsch (1962). Colorimetric Method for Determination of Total Lipids. Journal of Experimental Medicine, 135, 545-550.
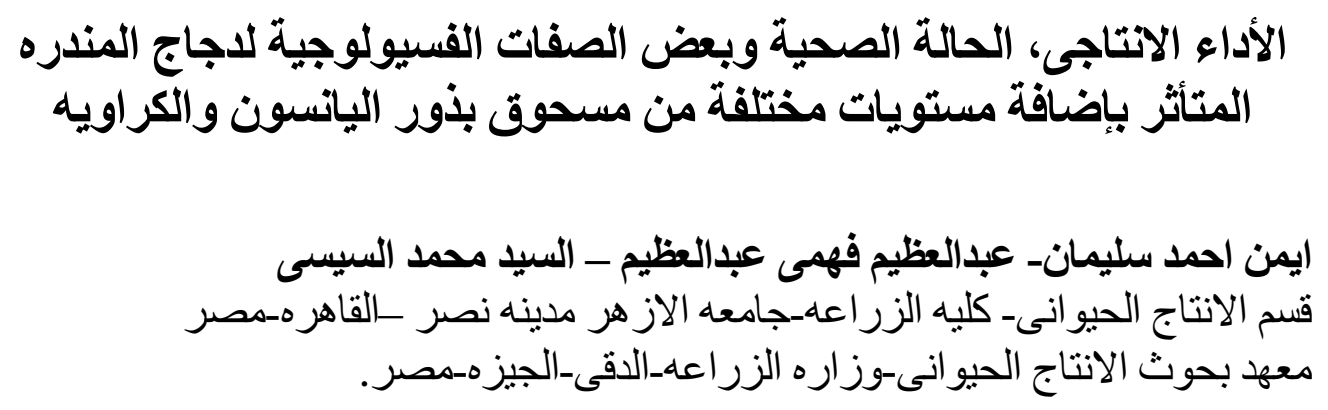

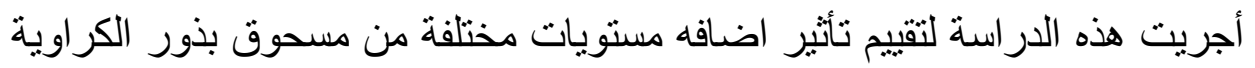

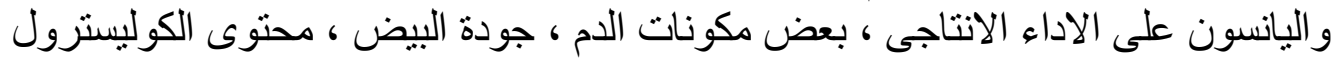

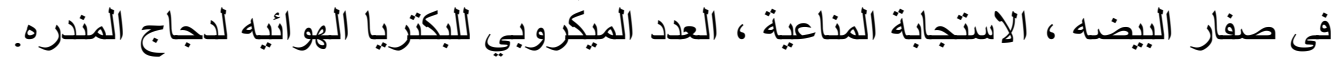

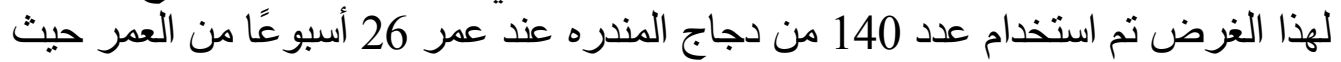

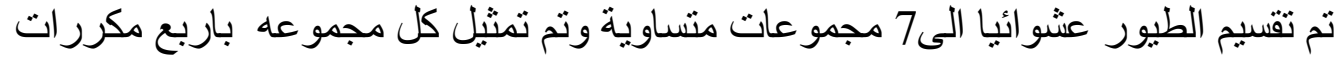

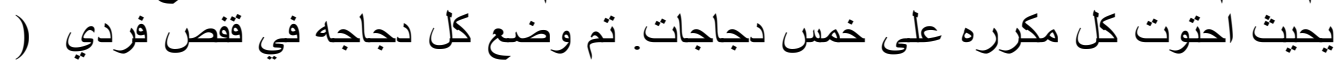

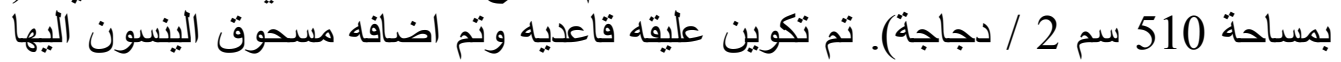

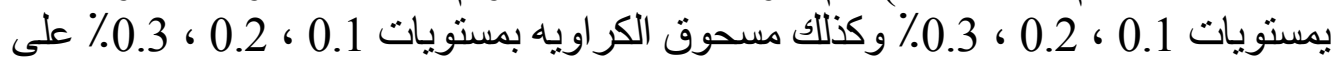

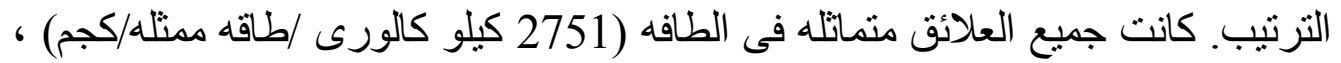
و البروتين (16.14\% بروتين خام).

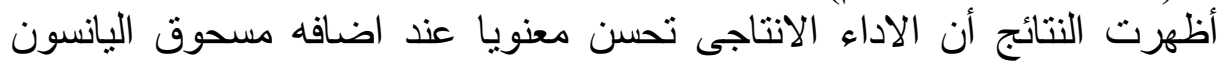

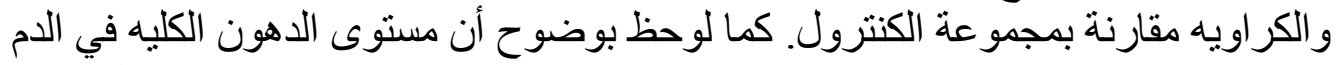

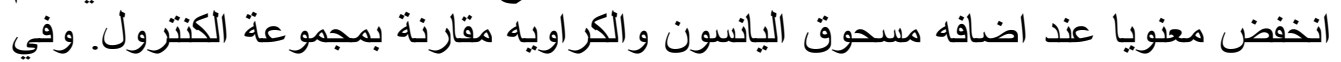

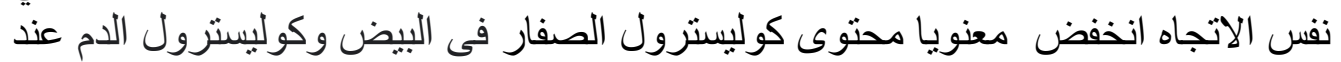
اضافه مسحوق اليانسون و الكر اويه مقارنة بمجمو عة الكنترول. 


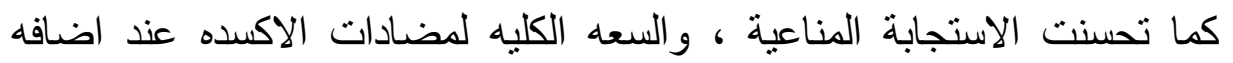

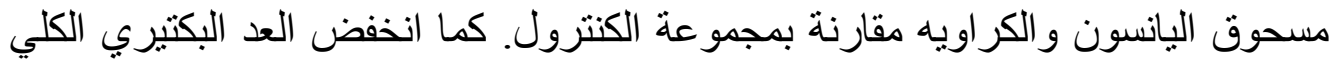

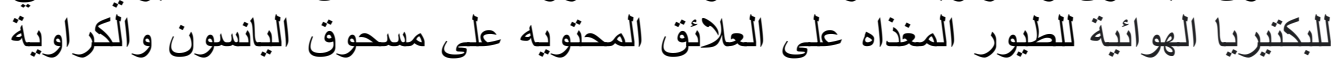

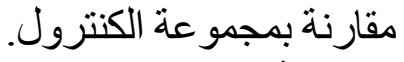

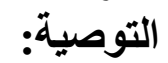

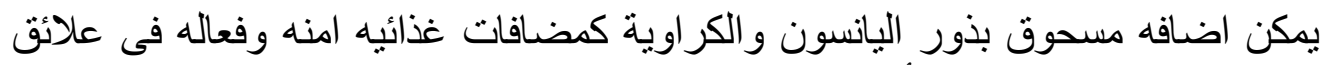

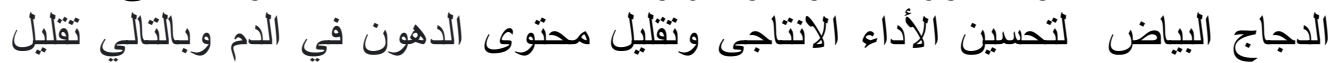
محتوى الكوليسترول في صفار البيض فى الإجاج البياض. 